\title{
Social Role Participation and Satisfaction With Life: A Study Among Patients With Ankylosing Spondylitis and Population Controls
}

Citation for published version (APA):

van Genderen, S., Plasqui, G., van der Heijde, D., van Gaalen, F., Heuft, L., Luime, J., Spoorenberg, A., Arends, S., Lacaille, D., Gignac, M., Landewe, R., \& Boonen, A. (2018). Social Role Participation and Satisfaction With Life: A Study Among Patients With Ankylosing Spondylitis and Population Controls. Arthritis Care and Research, 70(4), 600-607. https://doi.org/10.1002/acr.23304

Document status and date:

Published: 01/04/2018

DOI:

10.1002/acr.23304

Document Version:

Publisher's PDF, also known as Version of record

Document license:

Taverne

Please check the document version of this publication:

- A submitted manuscript is the version of the article upon submission and before peer-review. There can be important differences between the submitted version and the official published version of record.

People interested in the research are advised to contact the author for the final version of the publication, or visit the DOI to the publisher's website.

- The final author version and the galley proof are versions of the publication after peer review.

- The final published version features the final layout of the paper including the volume, issue and page numbers.

Link to publication

\footnotetext{
General rights rights.

- You may freely distribute the URL identifying the publication in the public portal. please follow below link for the End User Agreement:

www.umlib.nl/taverne-license

Take down policy

If you believe that this document breaches copyright please contact us at:

repository@maastrichtuniversity.nl

providing details and we will investigate your claim.
}

Copyright and moral rights for the publications made accessible in the public portal are retained by the authors and/or other copyright owners and it is a condition of accessing publications that users recognise and abide by the legal requirements associated with these

- Users may download and print one copy of any publication from the public portal for the purpose of private study or research.

- You may not further distribute the material or use it for any profit-making activity or commercial gain

If the publication is distributed under the terms of Article $25 \mathrm{fa}$ of the Dutch Copyright Act, indicated by the "Taverne" license above, 


\title{
Social Role Participation and Satisfaction With Life: A Study Among Patients With Ankylosing Spondylitis and Population Controls
}

\author{
SIMON VAN GENDEREN, ${ }^{1}$ GUY PLASQUI, ${ }^{1}$ DÉSIRÉE VAN DER HEIJDE, ${ }^{2}$ FLORIS VAN GAALEN, ${ }^{2}$ \\ LIESBETH HEUFT, ${ }^{3}$ JOLANDA LUIME, ${ }^{4}$ ANNEKE SPOORENBERG, ${ }^{5}$ SUZANNE ARENDS, ${ }^{5}$ \\ DIANE LACAILLE, ${ }^{6}$ MONIQUE GIGNAC, ${ }^{7}$ ROBERT LANDEWÉ, ${ }^{8}$ AND ANNELIES BOONEN ${ }^{1}$
}

Objective. Participation in society of persons with chronic diseases receives increasing attention. However, little is known about which components of participation are most relevant to life satisfaction. This study examines the association between several aspects of social role participation and satisfaction with life (SWL) in patients with ankylosing spondylitis (AS) compared to population controls.

Methods. In a cross-sectional study, participants completed the Social Role Participation Questionnaire (SRPQ) and SWL scale. The SRPQ assesses several dimensions of participation (importance, satisfaction with performance, and satisfaction with time and physical difficulty) in 11 roles representing 3 domains (interpersonal relations, leisure, and work). For individuals with AS and controls, the association between role domains and SWL was examined using linear regression for each participation dimension separately, in the total and the employed population, adjusting for age, sex, education, and income. Results. A total of 246 AS patients (mean \pm SD age $51 \pm 12$ years, 62\% males, mean \pm SD disease duration $17 \pm 12$ years) and 510 controls (mean \pm SD age $42 \pm 15$ years, 70\% males) were included. AS patients were more frequently (extremely) dissatisfied with life $(17.9 \%$ versus $8.6 \% ; P<0.05)$. In the total and the employed population, less physical difficulty and higher satisfaction with interpersonal relations and leisure were associated with higher SWL, and this was somewhat stronger in patients than in controls $(P<0.1)$. In employed controls, but not in employed patients, satisfaction with work was independently associated with SWL.

Conclusion. These findings highlight the importance of supporting persons with AS in ameliorating social role participation, particularly in areas like close relationships and leisure activities, which are typically ignored when treating AS.

\section{INTRODUCTION}

In an era where patient-centered care is being implemented in health care, social role participation of individuals with chronic diseases receives increasing attention from health professionals. The relevance of social role participation is supported by studies, revealing that patients identified several social roles as "valued life activities" (1-5). However, measuring and operationalizing participation is challenging, given that participation in social roles covers multiple

Supported by AbbVie.

${ }^{1}$ Simon van Genderen, MSc, Guy Plasqui, PhD, Annelies Boonen, MD, PhD: Maastricht University, Maastricht, The Netherlands; ${ }^{2}$ Désirée van der Heijde, MD, PhD, Floris van Gaalen, MD, PhD: Leiden University Medical Center, Leiden, The Netherlands; ${ }^{3}$ Liesbeth Heuft, MD, PhD: Sint Laurentius Hospital Roermond and Sint Jans Gasthuis Weert, Roermond and Weert, The Netherlands; ${ }^{4}$ Jolanda Luime, PhD: Erasmus Medical Center Rotterdam, Rotterdam, The Netherlands; ${ }^{5}$ Anneke Spoorenberg, MD, PhD, Suzanne Arends, PhD: University of Groningen, University Medical Center Groningen, and Medical Center Leeuwarden, Leeuwarden, The Netherlands; ${ }^{6}$ Diane Lacaille, MD, domains and can be assessed across various dimensions, such as role importance, satisfaction or, more typically in health-outcome research, difficulty with roles $(3,4)$.

The Social Role Participation Questionnaire (SRPQ) asks respondents to rate their participation in 11 specific (e.g., employment, intimate relationships, and physical leisure) and 1 general participation role across 4 dimensions: importance, satisfaction with time, satisfaction with performance, and physical difficulty (6-8). Previous studies in individuals with ankylosing spondylitis (AS) found that patients

MHSc: University of British Columbia, Vancouver, Canada, and Arthritis Research Centre of Canada, British Columbia, Canada; ${ }^{7}$ Monique Gignac, PhD: Institute for Work \& Health and University of Toronto, Toronto, Canada; ${ }^{8}$ Robert Landewé, MD, PhD: Amsterdam Medical Center, Amsterdam, The Netherlands.

Address correspondence to Simon van Genderen, MSc, Department of Internal Medicine, Division of Rheumatology, Maastricht University Medical Center, Prof. Debyelaan 25, 6202 AZ Maastricht, The Netherlands. E-mail: s.vangenderen@maastrichtuniversity.nl.

Submitted for publication November 21, 2016; accepted in revised form June 13, 2017. 


\section{Significance \& Innovations}

- A higher proportion of patients with ankylosing spondylitis report very low and low life satisfaction compared to population controls.

- Social role participation, and especially interpersonal relations and leisure activities, are associated with greater life satisfaction, and this is somewhat stronger in patients than in controls.

- In employed controls, but not in employed patients, work participation additionally contributes to life satisfaction. Additional research is needed to better understand this finding.

rated most social roles as important, and showed that role salience (i.e., importance) was often higher compared to population controls. In addition, patients with AS reported experiencing more physical difficulties when participating in roles and were less satisfied with their ability to perform in roles compared to population controls (9). Clear associations between the SRPQ and health outcomes, such as disease severity, depression, and even health care utilization, have been reported $(6,10)$. However, before recommending participation in social roles as a relevant outcome in AS, it is also important to understand the influence of social roles on patients' overall satisfaction with life (SWL).

From the perspective of several philosophies, an individual strives to achieve happiness or SWL. The Satisfaction With Life Scale (SWLS) was developed with the specific aim to "assess satisfaction with the respondent's life as a whole" $(11,12)$. The questionnaire contains 5 items and has been applied in several populations of healthy persons and persons with chronic disease $(13,14)$. As such, the SWLS offers the opportunity to evaluate the contribution of social role participation to life satisfaction, and results could support the validity of evaluating participation in AS in research and clinical practice. When social role participation is valuable for the SWL of healthy persons (9), it would be additionally insightful to understand whether social role participation is differently associated with SWL in patients compared to persons without chronic diseases. While an earlier study indicated that patients attached greater importance to participation in social roles, but experienced less satisfaction and more difficulties, it could well be that participation is even more important for patients than controls when examining overall life satisfaction. Evidence on the (differential) impact of social role participation on SWL would further support efforts to pay more attention to social role participation in the daily care of the patients.

The aim of this study was therefore to investigate the relationship between social role participation and SWL in patients with AS, and to understand whether this relationship is different when compared to population controls. It was hypothesized that, specifically, satisfaction with performance for each role domain would be associated with SWL, and that these associations would be stronger in patients compared to controls.

\section{PATIENTS AND METHODS}

Participants. Patients were recruited as part of a multicenter, cross-sectional questionnaire study, the Social Role Participation in Ankylosing Spondylitis Study. Patients older than age 18 years who were registered as having AS according to diagnosis-related codes or other diagnoses lists in 6 hospitals in The Netherlands, whose diagnosis was confirmed by the treating rheumatologist, and who were able to understand Dutch were invited by letter. Control subjects were recruited, parallel to the patient recruitment, from a national, online open panel of the research institute Ipsos (Amsterdam, The Netherlands). To ensure comparability between groups, and based upon the knowledge of patient characteristics of previously published observational studies in AS, the control group was requested to be age $>18$ years, with a group average of age 42 years, and have a male/female distribution of 3:1 (15). Control subjects were excluded if they indicated having any musculoskeletal disorder or were not familiar with the Dutch language (16). The study protocol was approved by the ethics committee of Maastricht University Medical Center (MEC azM/UM), and written informed consent was obtained from all patients.

Assessments. The online survey contained questions on demographic background, including age, sex, highest achieved education level (5 levels, dichotomized into having achieved a higher professional education or university degree, or not), and yearly income (8 categories ranging from $\leq € 20,000$ to $\geq € 140,000$, with an increase of $€ 20,000$ ). Social role participation was assessed using the validated extensive Dutch version of the SRPQ, which assesses the influence of health on 4 participation dimensions (role importance, satisfaction with time, satisfaction with performance, and physical difficulty) across 11 social roles and 1 general participation role. For the latter item, the respondent is asked to provide scores "while considering all previous social roles." Each role in each dimension can be scored on a 5-point Likert scale (where $1=$ not at all important/not at all satisfied/unable to do and $5=$ extremely important/extremely satisfied/no difficulty) (7). For 5 roles, subjects can indicate the role is not applicable: having a partner/intimate relationship, having (step/grand) children, having relationships with other family, employment, and current education status (i.e., following an educational course of professional relevance).

For further analyses, the SRPQ roles were classified into 3 domains: interpersonal relations (intimate relationships, [step/grand] children, other family, informal contacts, social activities, and religious, cultural, and community activities), leisure (physical leisure activities, hobbies, traveling, and/or vacationing), and work (employment). Separate scores for each dimension were calculated for the 3 role domains based on averages of applicable roles. For interpersonal relations and leisure, the domain scores were only calculated if subjects indicated that they participated in at least 2 roles.

To assess general health, the Medical Outcomes Study Short Form 36 (SF-36) health survey was included. The SF-36 contains 36 items and has 2 summary scores, the physical component summary (PCS) and mental component 
summary (MCS) scores. Both domain and summary scores range from 0 to 100, where higher scores reflect less difficulties/health problems (17).

The SWLS asks respondents to assess their agreement with 5 general statements related to feelings about life in general (e.g., "In most ways my life is close to my ideal." "I am satisfied with my life.”). Each item can be rated on a Likert scale (where $1=$ not at all agree to $7=$ totally agree). The total score ranges from 5 to 35 , where higher scores indicate more satisfaction with life $(11,18)$. Validated thresholds have been computed by the developers, who classify scores $\leq 9$ as extreme dissatisfaction, from 10 to 14 as dissatisfaction, from 15 to 19 as slight dissatisfaction, 20 as neutral life satisfaction, from 21 to 25 as slight satisfaction, from 26 to 30 as satisfaction, and from 31 to 35 as extreme satisfaction with life (19).

Patients additionally reported the date of diagnosis, whether they were currently treated with a biologic agent (anti-tumor necrosis factor [anti-TNF]), and completed the Bath Ankylosing Spondylitis Disease Activity Index (BASDAI) and the Bath Ankylosing Spondylitis Functional Index (BASFI). The BASDAI contains 6 questions assessing different aspects of disease activity in AS (total score ranging from 0 to 10; higher values indicate higher disease activity) (20). The BASFI determines the level of normal daily physical functioning of people with AS across 10 items, each representing different activities (total score ranging from 0 to 10; higher values indicate more disabilities) (21).

Statistical analysis. Characteristics of the study sample were described using means \pm SDs or proportions. Characteristics between patients and controls were compared by independent $t$-tests (SWLS, age, SF-36, PCS), MannWhitney U (SF-36 MCS), or chi-square (sex, being involved in specific social roles, being [extremely] [dis]satisfied with life) depending on the nature of the data.

Linear regression analyses were performed for patients and controls separately, using the scores on the SWLS as outcome, and participation in the 3 social role domains as the main explanatory variables. As the different participation dimensions represent partially overlapping constructs, with correlations between dimensions ranging from moderate (Spearman's rho $\geq 0.4$ ) to high (Spearman's rho $\geq 0.75$ ), the influence of each participation dimension was explored in a separate model. Within each dimension, the 11 social roles were combined into 3 larger social role domains, representing the average of the interpersonal roles, the average of the leisure roles, and employment. The 3 participation domains were added to a basic regression model containing age, sex, education, and income, as these were considered relevant determinants and/or potential confounders. Since a substantial proportion of subjects were not employed and thus had a missing score for the domain "participation in work," analyses were performed first in the total sample while ignoring the work domain, and secondly in the employed subsample by considering all 3 domains. To understand whether the general participation role would provide the same information as the 3 distinguished domains of social role participation, the models were repeated for each dimension of the general participation role instead of the domains (interpersonal relations, leisure, and work) in the total populations of patients and controls. The fit of the models with and without participation domains and between patients and controls were compared based on the explained variance $\left(R^{2}\right)$. To examine whether the changes in $R^{2}$ were statistically significant ( $P$ less than or equal to 0.05 ) when entering the participation domains or the general participation role to the model, the F-test was used. To test statistically whether social roles were differentially associated with SWL in patients and controls, the interaction terms "group (AS versus controls)*social role domain" were tested. An interaction was considered significant if the $P$ value was less than 0.1. Statistical analyses were performed using PASW Statistics, version 20 (SPSS).

\begin{tabular}{|c|c|c|c|}
\hline & $\begin{array}{l}\text { Patients with AS } \\
\quad(n=246)\end{array}$ & $\begin{array}{l}\text { Controls } \\
(n=510)\end{array}$ & $\boldsymbol{P}$ \\
\hline Male sex & $153(62)$ & $355(70)$ & 0.04 \\
\hline Age, years & $51 \pm 12(24-79)$ & $42 \pm 15(18-85)$ & $<0.001$ \\
\hline $\begin{array}{l}\text { Education level, higher professional or } \\
\text { university }\end{array}$ & $81(33)$ & $248(49)$ & $<0.001$ \\
\hline Income, $\leq € 40,000$ year & $150(61)$ & $184(43)+$ & $<0.001$ \\
\hline Diagnosis duration, years & $16.8 \pm 11.8(5-44)$ & - & - \\
\hline SF-36 PCS & $38.7 \pm 10.1(5.2-61.9)$ & $53.5 \pm 8.7(18.1-73.5)$ & $<0.001$ \\
\hline SF-36 MCS & $49.2 \pm 12.8(10.9-70.5)$ & $49.6 \pm 11.8(0.5-68.5)$ & 0.49 \\
\hline SWLS & $22.2 \pm 7.7$ & $24.7 \pm 6.6$ & $<0.001$ \\
\hline \multicolumn{4}{|l|}{ SRPQ roles potentially "not applicable" } \\
\hline Has intimate relationship & $187(79)$ & $371(73)$ & 0.11 \\
\hline Has (step/grand) children & $184(75)$ & $279(55)$ & $<0.001$ \\
\hline Has other family & $239(98)$ & $497(98)$ & 0.81 \\
\hline Employed & $140(57)$ & $396(78)$ & $<0.001$ \\
\hline Following education & $40(16)$ & $117(23)$ & 0.04 \\
\hline \multicolumn{4}{|c|}{$\begin{array}{l}\text { * Values are the number (percentage) or the mean } \pm \text { SD (minimum-maximum). AS }=\text { ankylosing spondylitis; SF- } 36= \\
\text { Medical Outcomes Study Short Form } 36 \text { health survey; PCS = physical component summary; MCS = mental component } \\
\text { summary; SWLS = Satisfaction With Life Scale; SRPQ = Social Role Participation Questionnaire. } \\
\text { † Missing data with } 425 \text { complete cases. }\end{array}$} \\
\hline
\end{tabular}




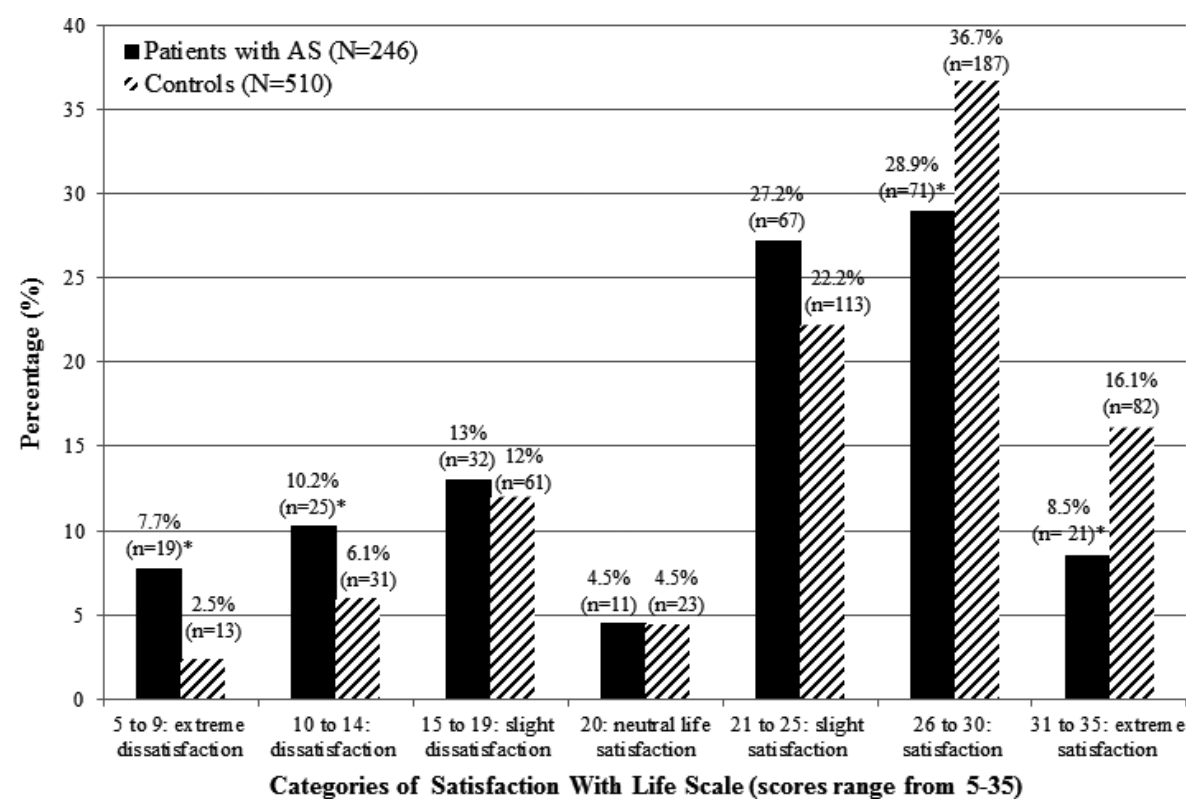

Figure 1. Percentage and absolute number of patients (solid bars; $n=246$ ) and controls (hatched bars; $n=510$ ) in each category of the Satisfaction With Life Scale. ${ }^{*}=$ a difference between patients and controls within the category $(P \leq 0.05)$. AS $=$ ankylosing spondylitis.

\section{RESULTS}

Samples. Of the 740 patients invited, 296 (40\%) agreed to participate and 246 (83\%) completed the questionnaire. Of the 2,767 controls invited, $784(28 \%)$ agreed to participate, and $510(65 \%)$ completed the questionnaire. Characteristics of both patients and controls are given in Table 1. Controls were more often male and were younger. In addition, a larger proportion had achieved a higher education or university degree, was employed, and had a yearly income $\geq € 40,000$. Moreover, a lower proportion of controls had step/grandchildren. Patients reported a mean \pm SD BASDAI score of $4.4 \pm 2.3$ and a BASFI score of $4.2 \pm 2.5$, and $50 \%$ were treated with a TNF inhibitor. Compared to controls, patients reported lower physical health but similar mental health.

On average, patients scored significantly lower on SWL compared to controls (mean \pm SD $22.2 \pm 7.7$ versus $24.7 \pm$ 6.6). A larger proportion of patients were (extremely) dissatisfied with life (17.9\% versus $8.6 \%$ ), while controls were more frequently (extremely) satisfied (52.8\% versus $37.4 \%$ ) (19) (Figure 1).

Participation in role domains and satisfaction with life in the total group of patients and controls. The explained variance of the basic model (age, sex, education, and income) was $\mathrm{R}^{2}=0.05$ in patients and $\mathrm{R}^{2}=0.06$ in controls (see Supplementary Table 1, available on the Arthritis Care $\&$ Research web site at http://onlinelibrary.wiley.com/doi/10.1002/ acr.23304/abstract). Only the yearly income was related with SWL in patients $(\beta=0.9, P<0.001)$ and controls $(\beta=1.06$, $P<0.001$ ). When adding the participation domains of interpersonal relations and leisure, the overall fit of all models $\left(\mathrm{R}^{2}\right)$ improved in both patients and controls (Table 2). In general, somewhat stronger improvements in model fit $\left(\mathrm{R}^{2}\right)$ were seen in patients compared to controls. The largest improvements in explained variance were seen in the models addressing the dimensions of satisfaction with role performance (model $\mathrm{R}^{2}=0.43$ ) in patients or of satisfaction with time (model $\mathrm{R}^{2}=0.24$ ) in controls. Notably, in persons with AS, the relative contribution of yearly income became negligible, when adding the social roles to models addressing the dimensions of satisfaction with time or satisfaction with performance. The interaction term group $\times$ participation was significant for the domain of interpersonal relations in the dimension of satisfaction with performance. This indicates that satisfaction with performance in interpersonal relations has a stronger association with SWL in patients compared to controls.

Participation in role domains and life satisfaction among employed subjects. In the employed sample, the total explained variance of the model with sociodemographic characteristics (basic model) provided an $\mathrm{R}^{2}$ of 0.07 for patients and of 0.06 for controls (see Supplementary Table 2, available on the Arthritis Care \& Research web site at http://onlinelibrary.wiley.com/doi/10.1002/acr.23304/ abstract). Similar to the total sample, only yearly income was related to SWL in both employed patients $(\beta=0.87, P=$ 0.003) and controls $(\beta=0.89, P<0.001)$.

When adding the participation domains interpersonal relations, leisure, and work (Table 3 ), again $\mathrm{R}^{2}$ improved significantly compared with the basic model. The largest improvements were seen in the models addressing satisfaction with time (total $\mathrm{R}^{2}=0.46$ in patients and total $\mathrm{R}^{2}=0.27$ in controls), but these improvements were very comparable when satisfaction with performance was added. While satisfaction with performance and with time spent in work were significantly associated with SWL in controls, such associations were not seen in patients. Of note, no association between difficulty with work and SWL in patients was observed. The associations between income and SWL lost 
Table 2. Association between the participation domains and satisfaction with life among AS patients and controls for each of the participation dimensions, separately*

\begin{tabular}{|c|c|c|c|c|c|c|c|c|}
\hline & \multicolumn{4}{|c|}{ Patients with AS (n = 246) } & \multicolumn{4}{|c|}{ Controls $(n=510)$} \\
\hline & $\mathbf{b}$ & SE & $\boldsymbol{P}$ & Partial R & $\mathbf{b}$ & SE & $\boldsymbol{P}$ & Partial R \\
\hline \multicolumn{9}{|l|}{ Importancet } \\
\hline Constant & 9.44 & 4.04 & 0.020 & & 13.38 & 2.09 & $<0.001$ & \\
\hline Age & 0.03 & 0.04 & 0.368 & 0.06 & 0.01 & 0.02 & 0.702 & 0.02 \\
\hline Male sex & -0.27 & 0.94 & 0.777 & -0.02 & 0.57 & 0.66 & 0.390 & 0.04 \\
\hline Income (per €20,000) & 0.81 & 0.26 & 0.002 & 0.20 & 0.94 & 0.22 & $<0.001$ & 0.20 \\
\hline Interpersonal relations & 2.16 & 0.78 & 0.006 & 0.18 & 2.26 & 0.51 & $<0.001$ & 0.21 \\
\hline Leisure & 0.22 & 0.71 & 0.756 & 0.02 & 0.05 & 0.49 & 0.921 & 0.01 \\
\hline \multicolumn{9}{|l|}{ Physical difficulty $\ddagger$} \\
\hline Constant & 1.24 & 3.57 & 0.729 & & -4.58 & 3.90 & 0.241 & \\
\hline Age & 0.05 & 0.04 & 0.137 & 0.10 & 0.04 & 0.02 & 0.027 & 0.11 \\
\hline Male sex & -0.67 & 0.87 & 0.443 & -0.05 & -0.31 & 0.63 & 0.627 & -0.02 \\
\hline Income (per €20,000) & 0.52 & 0.24 & 0.033 & 0.14 & 0.92 & 0.21 & $<0.001$ & 0.21 \\
\hline Interpersonal relations & 2.59 & 1.12 & 0.021 & 0.15 & 3.25 & 1.11 & 0.003 & 0.14 \\
\hline Leisure & 1.94 & 0.88 & 0.028 & 0.14 & 2.04 & 0.86 & 0.018 & 0.12 \\
\hline \multicolumn{9}{|l|}{ Satisfaction with performance§ } \\
\hline Constant & 1.14 & 2.31 & 0.622 & & 8.55 & 1.88 & $<0.001$ & \\
\hline Age & 0.04 & 0.03 & 0.211 & 0.08 & 0.05 & 0.02 & 0.014 & 0.12 \\
\hline Male sex & -0.25 & 0.74 & 0.738 & -0.02 & -0.32 & 0.62 & 0.601 & -0.03 \\
\hline University/higher education & -1.20 & 0.80 & 0.134 & -0.10 & -0.16 & 0.59 & 0.789 & -0.01 \\
\hline Income (per €20,000) & 0.34 & 0.21 & 0.104 & 0.11 & 0.86 & 0.21 & $<0.001$ & 0.20 \\
\hline Interpersonal relations & 3.63 & 0.73 & $<0.001$ & 0.31 & 1.64 & 0.55 & 0.003 & 0.14 \\
\hline Leisure & 2.36 & 0.60 & $<0.001$ & 0.25 & 1.73 & 0.51 & 0.001 & 0.17 \\
\hline \multicolumn{9}{|l|}{ Satisfaction with time $\mathbb{I}$} \\
\hline Constant & 0.68 & 2.34 & 0.772 & & 6.22 & 1.87 & 0.001 & \\
\hline Age & 0.01 & 0.03 & 0.822 & 0.02 & 0.02 & 0.02 & 0.323 & 0.05 \\
\hline Male sex & 0.58 & 0.75 & 0.439 & 0.05 & -0.05 & 0.60 & 0.938 & 0.00 \\
\hline Interpersonal relations & 3.71 & 0.73 & $<0.001$ & 0.31 & 2.44 & 0.51 & $<0.001$ & 0.23 \\
\hline Leisure & 2.60 & 0.59 & $<0.001$ & 0.27 & 2.12 & 0.47 & $<0.001$ & 0.22 \\
\hline \multicolumn{9}{|c|}{$\begin{array}{l}\text { * Participation domain scores range from } 1 \text { (not at all important/not at all satisfied/unable to do) to } 5 \text { (extremely important/extremely satis- } \\
\text { fied/no difficulty). Satisfaction with life scores range from } 5 \text { (extreme dissatisfaction) to } 35 \text { (extreme satisfaction). AS = ankylosing spondylitis. } \\
\text { F For AS patients: } \mathrm{R}=0.30\left(\mathrm{R}^{2}=0.09\right) \text {; for controls: } \mathrm{R}=0.34\left(\mathrm{R}^{2}=0.12\right) \\
\text { ₹ For AS patients: } \mathrm{R}=0.46\left(\mathrm{R}^{2}=0.21\right) \text {; for controls: } \mathrm{R}=0.40\left(\mathrm{R}^{2}=0.16\right) \\
\S \text { For AS patients: } \mathrm{R}=0.65\left(\mathrm{R}^{2}=0.43\right) \text {; for controls: } \mathrm{R}=0.44\left(\mathrm{R}^{2}=0.19\right) \\
\text { II For AS patients: } \mathrm{R}=0.65\left(\mathrm{R}^{2}=0.42\right) \text {; for controls: } \mathrm{R}=0.49\left(\mathrm{R}^{2}=0.24\right)\end{array}$} \\
\hline
\end{tabular}

significance in patients, in the models addressing the dimensions physical difficulty, satisfaction with time, or satisfaction with performance. The interaction terms group $\times$ participation domains were not significant, indicating the relative contribution of participation domains to SWL was not statistically different between employed patients compared to employed controls.

General participation role and satisfaction with life. When adding the score on the general participation role items of the SRPQ instead of the separate role domains to the basic model, the model fit improved again significantly across all dimensions in patients as well as controls (see Supplementary Table 3, available on the Arthritis Care $\mathcal{E}$ Research web site at http://onlinelibrary.wiley.com/doi/10. 1002/acr.23304/abstract), except for the dimension importance in patients. Notwithstanding, the changes of $\mathrm{R}^{2}$ when adding the general participation role were somewhat smaller than in models with the separate role domains. Among patients, the influence of yearly income on SWL became smaller, but remained a significant covariate.

\section{DISCUSSION}

This study aimed to understand whether participation by AS patients in social roles is associated with overall life satisfaction, and to gain insight whether patients differ in this respect with control without a chronic disease. First, it was found that more patients with AS experienced (extreme) dissatisfaction with life, and fewer reported (extreme) satisfaction when compared to population controls. Further, in patients and controls, participation in social roles was associated with higher SWL, and this relation was stronger in patients, although the test for interaction was not always significant. Within the participation domains, interpersonal relations contributed most to SWL in patients, while in 


\begin{tabular}{|c|c|c|c|c|c|c|c|c|}
\hline & \multicolumn{4}{|c|}{$\begin{array}{l}\text { Employed AS patients } \\
(n=140,56.9 \% \text { of total) }\end{array}$} & \multicolumn{4}{|c|}{$\begin{array}{c}\text { Employed controls } \\
(\mathrm{n}=396,77.7 \% \text { of total })\end{array}$} \\
\hline & b & SE & $\boldsymbol{P}$ & Partial R & b & SE & $\boldsymbol{P}$ & Partial R \\
\hline \multicolumn{9}{|l|}{ Importance +} \\
\hline Constant & 9.13 & 4.50 & 0.043 & & 13.84 & 2.35 & $<0.001$ & \\
\hline Age & 0.04 & 0.05 & 0.411 & 0.05 & 0.01 & 0.02 & 0.756 & 0.02 \\
\hline Male sex & -0.28 & 0.95 & 0.765 & -0.02 & 0.65 & 0.66 & 0.323 & 0.05 \\
\hline University/higher education & -0.15 & 1.00 & 0.883 & -0.01 & 0.17 & 0.62 & 0.783 & 0.01 \\
\hline Income (per €20,000) & 0.80 & 0.26 & 0.002 & 0.20 & 0.94 & 0.23 & $<0.001$ & 0.20 \\
\hline Interpersonal relations & 2.14 & 0.78 & 0.007 & 0.17 & 2.17 & 0.51 & $<0.001$ & 0.20 \\
\hline Leisure & 0.22 & 0.71 & 0.759 & 0.02 & 0.05 & 0.49 & 0.926 & 0.01 \\
\hline Work & 0.06 & 0.35 & 0.876 & 0.01 & -0.07 & 0.25 & 0.785 & -0.01 \\
\hline \multicolumn{9}{|l|}{ Physical difficulty } \\
\hline Constant & 1.72 & 4.87 & 0.725 & & -5.39 & 4.67 & 0.249 & \\
\hline Age & 0.06 & 0.05 & 0.296 & 0.09 & 0.00 & 0.03 & 0.868 & 0.01 \\
\hline Male sex & -0.94 & 1.07 & 0.383 & -0.08 & -0.55 & 0.67 & 0.409 & -0.05 \\
\hline University/higher education & -1.08 & 1.14 & 0.345 & -0.08 & 0.33 & 0.63 & 0.596 & 0.03 \\
\hline Income (per €20,000) & 0.38 & 0.28 & 0.183 & 0.12 & 0.87 & 0.22 & $<0.001$ & 0.21 \\
\hline Interpersonal relations & 2.10 & 1.47 & 0.157 & 0.12 & 2.40 & 1.30 & 0.067 & 0.10 \\
\hline Leisure & 2.63 & 1.19 & 0.029 & 0.19 & 2.98 & 1.02 & 0.004 & 0.16 \\
\hline Work & 0.04 & 0.82 & 0.966 & 0.00 & 0.45 & 0.68 & 0.503 & 0.04 \\
\hline \multicolumn{9}{|l|}{ Satisfaction with performance§ } \\
\hline Constant & 2.53 & 3.22 & 0.433 & & 10.68 & 2.03 & $<0.001$ & \\
\hline Age & 0.07 & 0.05 & 0.150 & 0.13 & 0.01 & 0.03 & 0.612 & 0.03 \\
\hline Male sex & -0.93 & 0.92 & 0.316 & -0.09 & -0.76 & 0.64 & 0.241 & -0.07 \\
\hline University/higher education & -1.18 & 0.99 & 0.236 & -0.10 & -0.02 & 0.61 & 0.980 & 0.00 \\
\hline Income (per €20,000) & 0.27 & 0.24 & 0.266 & 0.10 & 0.57 & 0.22 & 0.01 & 0.14 \\
\hline Interpersonal relations & 2.42 & 0.97 & 0.014 & 0.21 & 0.78 & 0.59 & 0.186 & 0.07 \\
\hline Leisure & 2.39 & 0.78 & 0.003 & 0.26 & 0.87 & 0.54 & 0.111 & 0.09 \\
\hline Work & 0.71 & 0.52 & 0.177 & 0.12 & 1.78 & 0.37 & $<0.001$ & 0.26 \\
\hline \multicolumn{9}{|l|}{ Satisfaction with timeII } \\
\hline Constant & 1.69 & 3.05 & 0.580 & & 7.17 & 2.06 & 0.001 & \\
\hline Age & 0.06 & 0.05 & 0.190 & 0.11 & 0.01 & 0.02 & 0.810 & 0.01 \\
\hline Male sex & 0.05 & 0.92 & 0.955 & 0.01 & -0.29 & 0.62 & 0.646 & -0.03 \\
\hline University/higher education & 0.11 & 0.97 & 0.911 & 0.01 & 1.25 & 0.59 & 0.034 & 0.12 \\
\hline Income (per €20,000) & 0.20 & 0.24 & 0.394 & 0.07 & 0.73 & 0.21 & 0.001 & 0.19 \\
\hline Interpersonal relations & 2.30 & 0.90 & 0.011 & 0.22 & 1.31 & 0.55 & 0.018 & 0.13 \\
\hline Leisure & 2.67 & 0.73 & $<0.001$ & 0.30 & 1.85 & 0.50 & $<0.001$ & 0.20 \\
\hline Work & 0.72 & 0.48 & 0.136 & 0.13 & 1.38 & 0.31 & $<0.001$ & 0.24 \\
\hline \multicolumn{9}{|c|}{$\begin{array}{l}\text { * Participation domain scores range from } 1 \text { (not at all important/not at all satisfied/unable to do) to } 5 \text { (extremely important/extremely satis- } \\
\text { fied/no difficulty). Satisfaction with life scores range from } 5 \text { (extreme dissatisfaction) to } 35 \text { (extreme satisfaction). AS = ankylosing spondylitis. } \\
\text { † For employed AS patients: } R=0.30\left(R^{2}=0.09\right) \text {; for employed controls: } R=0.34\left(R^{2}=0.11\right) \text {. } \\
\text { \# For employed AS patients: } R=0.49\left(R^{2}=0.24\right) \text {; for employed controls: } R=0.42\left(R^{2}=0.18\right) \text {. } \\
\text { \& For employed AS patients: } R=0.66\left(R^{2}=0.44\right) \text {; for employed controls: } R=0.48\left(R^{2}=0.23\right) \text {. } \\
\text { II For employed AS patients: } R=0.68\left(R^{2}=0.46\right) \text {; for employed controls: } R=0.52\left(R^{2}=0.27\right) \text {. }\end{array}$} \\
\hline
\end{tabular}

controls interpersonal relations and leisure related almost equally to the variance in SWL. Of interest, while in controls satisfaction with performance and time spent in work was associated with SWL independent of the other participation domains, none of the dimensions that characterize participation in work contributed independently to SWL in employed persons with AS.

The lower SWL of patients compared to controls is in line with the study hypothesis and has been found in a number of chronic diseases. Lamu and Olsen (14) showed that the presence of a chronic disease, such as arthritis, diabetes mellitus, or heart disease, had a negative relation with SWL (14). Also, the dominant role of the domain interpersonal relations is in line with findings of their study, showing that SWL was strongly related with predominantly social relationships, and to a lesser extent by income and health outcomes (EuroQol 5-domain, Short Form 6-dimension, and/or visual analog scale health $_{\text {(14). }}$ In concordance with findings of the study mentioned above, the role of income became negligible in patients when considering difficulties and satisfaction with social role participation. In contrast, the role of income remained important for controls, independent of social roles. Response shift and re-appraisal of the construct life satisfaction when being confronted with a chronic disease is a likely explanation for the differential effect of income on life satisfaction; apparently income becomes less relevant than social roles $(22,23)$. 
In contrast to income, none of the other covariates, i.e., age, sex, or education, were associated with SWL. This was surprising, especially for education, as a study into the construct validity of the SWLS in a general Dutch population $(\mathrm{n}=$ 3,402 ) revealed that persons with only a primary school education reported a lower life satisfaction (24). In view of the smaller sample size of our study, we had only a few persons with just a lower education achievement, and therefore contrasted lower and middle education achievement with higher education or university degree. Doing so, we might have missed lower satisfaction with life in the lowest educated persons. On the other hand, similar to the previous study, our findings confirm age and sex did not influence SWL.

While work is rated among the 3 most important social roles by patients and population subjects (9), current data suggest that for patients work has no independent value for SWL, additionally to interpersonal relations and leisure. It should be noted that only subjects that remained in the workforce contributed data to the analyses with work. It would be interesting to evaluate prospectively how loss of work affects life satisfaction.

The dimension role importance had only a low contribution to the variance in SWL. Although role importance is of interest because it signals potential differences in the areas of life that matter to individuals, it seems less relevant by helping to understand whether someone is satisfied with their life (10). Additional multivariable models in patients, in which scores for role importance were used to weigh scores for the satisfaction with time, satisfaction with performance, or physical difficulty dimensions (3), did not meaningfully influence the strength of association between role domains and SWL, nor did it improve to model fit (data not shown). Despite the conceptual relevance of the importance dimension, it remains unclear how to deal with it in the light of exploring its value in the full construct of social role participation (10). On this line it should be acknowledged that it is not surprising that the satisfaction with time and satisfaction with performance dimensions were more strongly associated with SWL than the other dimensions, given their similarities with the life satisfaction construct, with which they were associated. Therefore, some circular reasoning or deterministic modeling was likely present. However, we should not ignore that physical difficulty with role performance was also strongly associated with life satisfaction.

Some limitations need to be recognized. First, due to cross-sectional design, no causality can be claimed. Secondly, the SRPQ contains 11 roles, but our previous studies, including a confirmatory analysis, indicated large correlations between several roles $(10,25)$. Guided by literature rather than statistical approaches (e.g., factor analyses), we grouped the 11 roles in 3 domains: interpersonal relations, leisure, and work. Of interest, when repeating the analyses with the general participation role instead of domains, the results were comparable overall. In case details about a specific role (domains) are less relevant, a single participation item can still provide valid and meaningful information $(1,3,25)$. Finally, the models explained up to $43 \%$ of the adjusted variance of SWL in patients and $24 \%$ in controls. Especially in patients, these are quite good model fits. Notwithstanding, other variables that are likely associated with SWL, such as level of health impairments, experience social inequality, personality traits, independence, and anxiety for the future, likely contribute. Although it was not the purpose of our study to understand the construct of life satisfaction, it would be interesting to understand SWL in persons with chronic diseases (26).

Our study provides innovative and relevant findings. While the ultimate aim of care in rheumatology is to improve SWL, the current data suggest we should not ignore the contribution of social role participation. Health care professionals could therefore address social roles when discussing care and treatment plans with patients. Further research should clarify which patients require help in improving physical performance and satisfaction with 1 or more roles and which support programs might be effective in reaching this goal.

In conclusion, this study shows that patients with AS indicated a lower SWL than population controls. More physical difficulties and lower satisfaction with performance, and time with interpersonal relations were related with a lower life satisfaction. Satisfaction regarding the performance and time spent with work was independently associated with SWL in employed controls but not in employed patients.

\section{ACKNOWLEDGMENTS}

The authors thank patient research partners Marlou Essers (who died prior to completion of the project) and Marianne Osseweijer for their contributions.

\section{AUTHOR CONTRIBUTIONS}

All authors were involved in drafting the article or revising it critically for important intellectual content, and all authors approved the final version to be submitted for publication. Mr. van Genderen had full access to all of the data in the study and takes responsibility for the integrity of the data and the accuracy of the data analysis.

Study conception and design. Van Genderen, Plasqui, Lacaille, Gignac, Boonen.

Acquisition of data. Van Genderen, Plasqui, van der Heijde, van Gaalen, Heuft, Lulme, Spoorenberg, Arends, Boonen.

Analysis and interpretation of data. Van Genderen, Plasqui, Landewé, Boonen.

\section{ROLE OF THE STUDY SPONSOR}

AbbVie had no role in the study design or in the collection, analysis, or interpretation of the data, the writing of the manuscript, or the decision to submit the manuscript for publication. Publication of this article was not contingent upon approval by AbbVie.

\section{REFERENCES}

1. World Health Organization. ICF: International Classification of Functioning, Disability and Health. Geneva: WHO; 2001.

2. Badley EM. Enhancing the conceptual clarity of the activity and participation components of the International Classification of Functioning, Disability, and Health. Soc Sci Med 2008;66:2335-45.

3. Dijkers MP. Issues in the conceptualization and measurement of participation: an overview. Arch Phys Med Rehabil 2010;91:5-16. 
4. Eyssen IC, Steultjens MP, Dekker J, Terwee CB. A systematic review of instruments assessing participation: challenges in defining participation. Arch Phys Med Rehabil 2011;92: S983-97.

5. Katz P, Morris A, Gregorich S, Yazdany J, Eisner M, Yelin E, et al. Valued life activity disability played a significant role in self-rated health among adults with chronic health conditions. J Clin Epidemiol 2009;62:S158-66.

6. Davis AM, Palaganas MP, Badley EM, Gladman DD, Inman RD, Gignac MA. Measuring participation in people with spondyloarthritis using the social role participation questionnaire. Ann Rheum Dis 2011;70:1765-9.

7. Gignac MA, Backman CL, Davis AM, Lacaille D, Cao X, Badley EM. Social role participation and the life course in healthy adults and individuals with osteoarthritis: are we overlooking the impact on the middle-aged? Soc Sci Med 2013;81:87-93.

8. Gignac MA, Backman CL, Davis AM, Lacaille D, Mattison CA, Montie P, et al. Understanding social role participation: what matters to people with arthritis? J Rheumatol 2008;35: $1655-1736$.

9. Van Genderen S, Plasqui G, Landewé R, Lacaille D, Arends S, van Gaalen F, et al. Social role participation in patients with ankylosing spondylitis: a cross-sectional comparison with population controls. Arthritis Care Res (Hoboken) 2016;68:1899-190.

10. Van Genderen S, Plasqui G, Lacaille D, Arends S, van Gaalen F, van der Heijde D, et al. Social role participation questionnaire for patients with ankylosing spondylitis: translation into Dutch, reliability and construct validity. RMD Open 2016;2:e000177.

11. Diener E, Emmons RA, Larsen RJ, Griffin S. The Satisfaction With Life Scale. J Pers Assess 1985;49:71-5.

12. Pavot W, Diener E. Review of the Satisfaction With Life Scale. Psychol Assess 1993;5:164-72.

13. Coty MB, Wallston KA. Roles and well-being among healthy women and women with rheumatoid arthritis. J Adv Nurs 2008;63:189-98.

14. Lamu AN, Olsen JA. The relative importance of health, income and social relations for subjective well-being: an integrative analysis. Soc Sci Med 2016;152:176-85.

15. Sieper J, Braun J, Rudwaleit M, Boonen A, Zink A. Ankylosing spondylitis: an overview. Ann Rheum Dis 2002;61:8-18.
16. Sangha O, Stucki G, Liang MH, Fossel AH, Katz JN. The self-administered comorbidity questionnaire: a new method to assess comorbidity for clinical and health services research. Arthritis Rheum 2003;49:156-63.

17. Ware Jr JE, Kosinski M, Bayliss MS, McHorney CA, Rogers WH, Raczek A. Comparison of methods for the scoring and statistical analysis of SF-36 health profile and summary measures: summary of results from the Medical Outcomes Study. Med Care 1995;33:264-79.

18. Arrindell WA, Meeuwesen L, Huyse FJ. The Satisfaction With Life Scale (SWLS): psychometric properties in a nonpsychiatric medical outpatients sample. Pers Individ Dif 1991;12:117-23.

19. Pavot W, Diener E. The Satisfaction With Life Scale and the emerging construct of life satisfaction. J Posit Psychol 2008; 3:137-52.

20. Garrett S, Jenkinson T, Kennedy LG, Whitelock H, Gaisford $\mathrm{P}$, Calin A. A new approach to defining disease status in ankylosing spondylitis: the Bath Ankylosing Spondylitis Disease Activity Index. J Rheumatol 1994;21:2286-91.

21. Calin A, Garrett S, Whitelock H, Kennedy LG, O’Hea J, Mallorie P, et al. A new approach to defining functional ability in ankylosing spondylitis: the development of the Bath Ankylosing Spondylitis Functional Index. J Rheumatol 1994;21: 2281-5.

22. Schwartz CE. Applications of response shift theory and methods to participation measurement: a brief history of a young field. Arch Phys Med Rehabil 2010;91:38-43.

23. Schwartz CE, Rapkin BD. Reconsidering the psychometrics of quality of life assessment in light of response shift and appraisal. Health Qual Life Outcomes 2004;2:16.

24. Van Beuningen J. Satisfaction With Life Scale: examining construct validity. Heerlen (The Hague): Statistics Netherlands; 2012.

25. Oude Voshaar M, van Onna M, van Genderen S, van de Laar M, van der Heijde D, Heuft L, et al. Development and validation of a short form of the Social Role Participation Questionnaire in patients with ankylosing spondylitis. J Rheumatol 2016;43:1386-92.

26. Diener E, Suh E, Lucas RE, Smith HL. Subjective well-being: three decades of progress. Psychol Bull 1999;125:276-302. 